\title{
A comparison of methods for the estimation of the proportion of microbial nitrogen in duodenal digesta, and of correction for microbial contamination in nylon bags incubated in the rumen of sheep
}

\author{
BY P. M. KENNEDY, ${ }^{*}$ G. P. HAZLEWOOD† AND L. P. MILLIGAN \\ Department of Animal Science, The University of Alberta, Edmonton, \\ Alberta T6G 2P5, Canada
}

(Received 15 December 1983 - Accepted 25 April 1984)

1. Four sheep, each fitted with cannulas in the rumen and proximal duodenum, were given two diets (1390 $\mathrm{g}$ dry matter (DM)/d) consisting of lucerne (Medicago sativa) pellets $(24 \cdot 2 \mathrm{~g}$ nitrogen $/ \mathrm{kg} \mathrm{DM})$ plus pelleted reed canary grass (Phalaris arundinacea; $14.1 \mathrm{~g} \mathrm{~N} / \mathrm{kg} \mathrm{DM})$ or chopped hay $(11.8 \mathrm{~g} \mathrm{~N} / \mathrm{kg} \mathrm{DM})$ at intervals of $2 \mathrm{~h}$. Flow of duodenal digesta measured by reference to the markers ${ }^{51} \mathrm{Cr}$-EDTA and ${ }^{103} \mathrm{Ru}$-phenanthroline indicated a net gain of 5.8-7.5 g non-ammonia-N (NAN) between mouth and duodenum.

2. The proportion of microbial $\mathrm{N}$ in duodenal digesta $\mathrm{N}$ was estimated using ${ }^{15} \mathrm{~N}$ and ${ }^{35} \mathrm{~S}$ incorporation into bacteria and digesta. Two methods of analysis for ${ }^{35} \mathrm{~S}$ content, the Bird \& Fountain (1970; B\&F method) and the Mathers \& Miller (1980; M\&M method), were used. $\left({ }^{15} \mathrm{NH}_{4}\right)_{2} \mathrm{SO}_{4}$ and $\mathrm{Na}_{2}{ }^{35} \mathrm{SO}_{4}$ were infused into the rumen for $3.5 \mathrm{~d}$ before and $4.0 \mathrm{~d}$ during sampling. A bacterial fraction was prepared from the fluid phases of sampled duodenal digesta and rumen contents by differential centrifugation. In addition, samples of ground canary grass and of lucerne were incubated in nylon bags in the rumen for 3-48 h during the infusion.

3. Each of the ${ }^{35} \mathrm{~S}$ analytical methods yielded similar values of ${ }^{35} \mathrm{~S}$ content of isolated rumen or duodenal bacteria, but there was more $(P<0.05)$ incorporation of ${ }^{15} \mathrm{~N}$ into rumen than into duodenal bacteria. Relative to values obtained using the $M \& M$ method and ${ }^{15} \mathrm{~N}$ incorporation, the $B \& F$ method for $S$ analysis yielded higher $(P<0.05)$ estimates of microbial content of duodenal digesta from sheep given chopped reed canary grass.

4. ${ }^{35} \mathrm{~S}$ activity associated with washed nylon-bag residues increased rapidly with time-period of incubation and was substantially greater $(P<0 \cdot 05)$ when analysed by the B\&F method compared with the M\&M method. The ${ }^{35} \mathrm{~S}$ content (/g DM) of adherent bacteria removed from nylon-bag residues by homogenization in a second experiment varied from 0.65 to 1.88 that of free-living bacteria isolated from rumen fluid by differential centrifugation.

5. The difference in ${ }^{35} \mathrm{~S}$ content in digesta and nylon-bag residues as measured using the two analytical methods was considered in relation to ${ }^{35} \mathrm{~S}$-labelled extracellular material postulated to be produced by bacteria adherent to plant residues. Estimates of disappearance of dietary $\mathrm{N}$ from nylon bags after correction for microbial contamination indicated a disparity with estimates based on in vivo information.

Quantitative determination of dietary protein which escapes rumen fermentation is central to recently proposed systems which utilize values for protein degradability and efficiency of microbial growth to derive estimates of protein flow to the small intestine (e.g. Agricultural Research Council, 1980). However, in the absence of a marker specific for dietary protein, estimation in vivo of dietary protein degradability requires that values for microbial and endogenous protein be subtracted from the flow of non-ammonia-nitrogen (NAN) to the small intestine.

The most reliable methods for determining the microbial portion of the NAN flowing into the small intestine appear to be those using a nuclide label, normally ${ }^{35} \mathrm{~S}$ or ${ }^{15} \mathrm{~N}$, which is incorporated into microbes after infusion of the label into the rumen (e.g. Mathison \& Milligan, 1971; Leibholz, 1972; Beever et al. 1974; Mathers \& Miller, 1980). Measurements

Present addresses: * Division of Tropical Animal Science, CSIRO, P.M.B. Aitkenvale, Queensland 4814, Australia. $\dagger$ Department of Biochemistry, AFRC Institute of Animal Physiology, Babraham, Cambridge CB2 4AT. 
based on ${ }^{35} \mathrm{~S}$ and ${ }^{15} \mathrm{~N}$ were found to give reasonably similar results for microbial flow (Kennedy \& Milligan, 1978b; Siddons et al. 1982), although the ${ }^{35}$ S-based values ranged from 0.10 higher (Kennedy \& Milligan, 1978b) to 0.25 lower (Siddons et al. 1982) than values obtained by reference to ${ }^{15} \mathrm{~N}$. The effect of estimation of ${ }^{35} \mathrm{~S}$ as cystine (Leibholz, 1972), methionine (Beever et al. 1974; Siddons et al. 1982), protein-bound ${ }^{35} \mathrm{~S}$ (Mathers \& Miller, 1980 ) or organically-bound ${ }^{35} \mathrm{~S}$ (Hume, 1974; Kennedy \& Milligan, 1978 $a, b$ ) on estimates of microbial flow, has not been determined.

The purpose of the experiment reported here was to compare values of microbial flow obtained by reference to incorporation of ${ }^{15} \mathrm{~N}$, protein-bound ${ }^{35} \mathrm{~S}$ (Mathers \& Miller, 1980) and organically-bound ${ }^{35} \mathrm{~S}$ (Hume, 1974; Kennedy \& Milligan, 1978 a,b) in bacteria isolated from the fluid phase of rumen and duodenal digesta. The two methods of ${ }^{35} \mathrm{~S}$ analysis were chosen for their relative simplicity, and differed in the approach taken to account for ${ }^{35} \mathrm{SO}_{4}{ }^{2-}$ contamination. In one (Mathers \& Miller, 1980; $\mathrm{M} \& \mathrm{M}$ method), ${ }^{35} \mathrm{~S}$ was determined after precipitation of free ${ }^{35} \mathrm{SO}_{4}{ }^{2-}$ as the barium salt, following performic acid oxidation and acid hydrolysis (6 M-hydrochloric acid, $\left.22 \mathrm{~h}, 100^{\circ}\right)$. In the other, based on the reduction of sulphate by a reducing mixture of acids (Bird \& Fountain, 1970; B\&F method), organicallybound ${ }^{35} \mathrm{~S}$ was calculated by difference from total ${ }^{35} \mathrm{~S}$ content and reducible- ${ }^{35} \mathrm{~S}$ content. In addition, the use of the markers to allow estimation of the amount of microbial $\mathbf{N}$ that is present in the contents of nylon bags incubated in situ for the purpose of measuring rate of forage $\mathrm{N}$ digestion in the rumen (see Mathers \& Aitchison, 1981) was investigated.

\section{EXPER I MENT A L}

Animals and diets

Four Suffolk wethers, weighing 43-47 kg, each fitted with a rumen cannula and a ' $T$ '-piece cannula in the proximal duodenum were used. They were housed in individual metabolism cages at $20-25^{\circ}$ with continuous illumination. Diets comprised reed canary grass (Phalaris arundinacea) in either the pelleted form $(14.1 \mathrm{~g} \mathrm{~N}, 726 \mathrm{~g}$ cell-wall constituents (CWC)/ $\mathrm{kg}$ dry matter (DM), $1210 \mathrm{~g} \mathrm{DM} / \mathrm{d})$ or as chopped hay $(11.8 \mathrm{~g} \mathrm{~N}, 713 \mathrm{~g} \mathrm{CWC} / \mathrm{kg} \mathrm{DM}, 1190 \mathrm{~g}$ $\mathrm{DM} / \mathrm{d}$ ), together with pelleted lucerne (Medicago sativa, $24.2 \mathrm{~g} \mathrm{~N}, 479 \mathrm{~g} \mathrm{CWC} / \mathrm{kg} \mathrm{DM}$, $190 \mathrm{~g} \mathrm{DM} / \mathrm{d}$ ). Diets were given at $2 \mathrm{~h}$ intervals in approximately equal amounts and were consumed to the extent of $0.89-0.93$ (chopped) or 1.0 (pelleted) of the amounts offered.

\section{Experimental procedure}

Expt 1. Four sheep were given pelleted lucerne. In addition to the pelleted lucerne, two of the sheep were given pelleted reed canary grass, and two sheep received chopped reed canary grass. After $14 \mathrm{~d}$ adaptation to the diet, jugular catheters were inserted and blood and rumen fluid were collected over $48 \mathrm{~h}$ during intravenous infusion of $\left[{ }^{15} \mathrm{~N}\right] \mathrm{urea}$ for another purpose.

After $24 \mathrm{~h}$, a primed continuous infusion of markers into the rumen was started. The infusion solution contained $\mathrm{Na}_{2}{ }^{35} \mathrm{SO}_{4}(4.4 \mathrm{MBq}, 53 \mathrm{mg} \mathrm{S} / 1),{ }^{103} \mathrm{Ru}$-phenanthroline complex $(0.73 \mathrm{MBq}, 6 \mu \mathrm{g} \mathrm{Ru} / 1)$ prepared by the method of Tan et al. (1971), ${ }^{51} \mathrm{Cr}-\mathrm{EDTA}(4.4 \mathrm{MBq}$, $0.15 \mathrm{mg} \mathrm{Cr} / 1)$ and $\left({ }^{15} \mathrm{NH}_{4}\right)_{2} \mathrm{SO}_{4}\left(68 \mathrm{mg}{ }^{15} \mathrm{~N} / \mathrm{l}\right)$. After a priming dose $(5 \mathrm{ml})$ equivalent in marker quantity to $10 \mathrm{~h}$ of infusion, infusions $(20 \mathrm{ml} / \mathrm{h})$ were continued for $7.5 \mathrm{~d}$. After $(40 \mathrm{~h}$ of intraruminal infusion, four nylon bags per sheep per incubation period were sequentially inserted during $100 \mathrm{~h}$ to give incubation periods of $3,6,12,18,24$ and $48 \mathrm{~h}$. The bags $(90 \times 170 \mathrm{~mm}$ ) were of $53 \mu \mathrm{m}$ porosity (Nitex nylon monofilament screen cloth; Tetko Inc., Elmsford, NY 10523, USA) and contained either air-dried reed canary grass ( $3 \mathrm{~g}$ ) or lucerne hay $(3 \mathrm{~g})$, plus three glass marbles as weights. Each forage had been ground through a $3 \mathrm{~mm}$ screen. For each pair of sheep given a particular diet (containing either pelleted or chopped reed canary grass) one received bags containing canary grass, while the 
other sheep received bags containing lucerne. On removal from the rumen, bags were washed briefly to remove adhering digesta and were then manipulated for $1 \mathrm{~min}$ in warm water to remove rumen fluid and non-adherent bacteria. Bacteria adherent to plant residues within the nylon bags were released by homogenization (Gillett et al. 1983; Mackie et al. 1983). Saline ( $9 \mathrm{~g}$ sodium chloride $/ 1)$ was added $(1.5 \mathrm{ml} / \mathrm{g}$ wet weight) and samples were treated with a Polytron homogenizer (Brinkmann Instruments, Rexdale, Canada) for 1 min at $15000 \mathrm{rev} . / \mathrm{min}$. The homogenate was strained through four layers of cheesecloth and the residue washed with saline. Released bacteria were harvested by differential centrifugation as described below. To ensure complete removal of small particles of plant material produced during homogenization, harvested bacteria were resuspended in distilled water and overlaid on to sucrose solution $(5 \mathrm{ml}, 400 \mathrm{~g} / \mathrm{l})$. Following centrifugation $(1000 \mathrm{~g}$, 5-10 min), bacteria free of plant material were recovered from above the water/sucrose interface and were washed by further centrifugation. The absence of contaminating plant material from bacterial preparations was confirmed by phase-contrast microscopy.

Twelve samples of rumen fluid $(60 \mathrm{ml})$ and of duodenal digesta ('day' collection 09.00 -21.00 hours, $100 \mathrm{ml}$; ' night' collection $21.00-09.00$ hours, $50 \mathrm{ml}$ ) were taken during the final $95 \mathrm{~h}$ of infusion at intervals of $8 \cdot 5-9.5 \mathrm{~h}$ to provide four samples at each of $0.5,1.0$ and $1.5 \mathrm{~h}$ after feeding. Bacteria were prepared from the fluid phase of all rumen samples and 'day' duodenal samples by differential centrifugation of 40 -g-samples at $1000 \mathrm{~g}\left(1 \mathrm{~min}, 5^{\circ}\right)$ followed by $20000 \mathrm{~g}\left(20 \mathrm{~min}, 5^{\circ}\right)$ for the supernatant fraction. The bacteria were washed with saline and water by centrifugation $(20000 \mathrm{~g})$ before being freeze-dried. Rumen fluid (10 ml plus one drop concentrated sulphuric acid) and duodenal digesta $(50 \mathrm{ml})$ were separately combined for each animal into 'day' and 'night' samples and frozen. Blood samples $(10 \mathrm{ml})$ were taken from the jugular vein for another purpose.

Expt 2. Because the harvest of bacteria adherent to nylon-bag residues was insufficient for analysis in Expt 1, the ${ }^{35} \mathrm{~S}$ content of adherent bacteria was examined in a second experiment. All four sheep used in the previous trial were given the diet of chopped reed canary grass and lucerne pellets used in Expt 1 . After an adaptation period of $7 \mathrm{~d}, \mathrm{Na}_{2}{ }^{35} \mathrm{SO}_{4}$ (3.7 MBq, $53 \mathrm{mg} \mathrm{S} / 1)$ was infused $(20 \mathrm{ml} / \mathrm{h})$ into the rumen for $7.5 \mathrm{~d}$. Bags containing ground $(3 \mathrm{~mm})$ reed canary grass were incubated in situ sequentially for 6, 12, 24 or $48 \mathrm{~h}$ as described for Expt 1. Residues from sixteen bags comprising four from each sheep at each incubation time were bulked, washed to remove non-adherent bacteria and subjected to homogenization. Detached bacteria were harvested as previously described. Two bulked preparations of the free-living bacteria from rumen fluid were made. The procedure of Expt 1 was followed for one preparation; for the other, immediately after washing with saline, the uppermost layer of the pellet (loosely sedimented bacteria) was separated by gently swirling with the residual saline (approximately $5 \mathrm{ml}$ ). The two separate bacterial preparations were then washed with water.

\section{Analytical methods}

$\mathrm{DM}$, organic matter (OM), CWC and $\mathrm{N}$ were determined as described previously (Kennedy \& Milligan, 1978b). Acid-detergent fibre (ADF) was determined by the method of Goering \& Van Soest (1970). ${ }^{15} \mathrm{~N}$ was estimated in triplicate using a mass spectrometer (Model 602; VG Micromass Ltd, Winsford, Cheshire, UK). ${ }^{51} \mathrm{Cr}$ and ${ }^{103} \mathrm{Ru}$ were estimated using a gamma-spectrometer (Gamma 8000; Beckman Instruments, Irvine, CA 92713, USA).

Organic ${ }^{35} \mathrm{~S}$ was determined in triplicate in isolated bacteria, duodenal digesta and nylon-bag residues by the method of Bird \& Fountain (1970) which also yielded estimates of specific radioactivity and $S$ concentration. The ratio of ${ }^{35} \mathrm{~S}: \mathrm{NAN}$ (non-ammonia-N) was measured by the method of Mathers \& Miller (1980). In the latter method, ${ }^{103} \mathrm{Ru}$ and ${ }^{51} \mathrm{Cr}$ were found to be removed during the filtration step, allowing assay of ${ }^{35} \mathrm{~S}$ in the absence of gamma-emitters. 


\section{Calculations}

Flow of $\mathrm{N}$ into the small intestine was calculated by reference to both ${ }^{103} \mathrm{Ru}$ and ${ }^{51} \mathrm{Cr}$ in bulked duodenal digesta, with allowance for absorption of ${ }^{51} \mathrm{Cr}$ from the reticulo-rumen, omasum and abomasum (Faichney, 1980). The proportion of duodenal NAN which was attributable to microbes was calculated as $\left({ }^{15} \mathrm{~N}\right.$ and $\mathrm{M} \& \mathrm{M}$ methods):

$$
\frac{{ }^{15} \mathrm{~N}-\mathrm{NAN} \text { or }{ }^{35} \mathrm{~S}: \mathrm{NAN} \text { content of duodenal digesta }}{{ }^{15} \mathrm{~N}-\mathrm{NAN} \text { or }{ }^{35} \mathrm{~S}: \text { NAN content of bacteria }}
$$

or alternatively as (B\&F method):

specific radioactivity of organic ${ }^{35} \mathrm{~S}$ in duodenal digesta $\times \frac{\text { organic } S}{\text { NAN }}$ of duodenal digesta

specific radioactivity of organic ${ }^{35} \mathrm{~S}$ in bacteria $\times \frac{\text { organic } S}{\text { NAN }}$ of bacteria

\section{Statistical methods}

Significance of differences obtained using the three markers $\left({ }^{35} \mathrm{~S}, \mathrm{~B} \& \mathrm{~F}\right.$ method or $\mathrm{M} \& \mathrm{M}$ method, ${ }^{15} \mathrm{~N}$ ) was tested by $t$ test using the within-animal variation to estimate analytical error $(8 \mathrm{df})$.

\section{RESULTS}

Expt 1. There were no significant differences in estimated flow of duodenal digesta when calculated from either the ${ }^{51} \mathrm{Cr}$ or ${ }^{103} \mathrm{Ru}$ contents of $24 \mathrm{~h}$ samples ('day' plus 'night' results combined), indicating that samples obtained from the duodenal cannula were representative of digesta flowing in the duodenum. Expressed as proportions, agreement between flows using the two markers was within 0.01 (SE 0.01). In addition, use of ${ }^{103} \mathrm{Ru}$ as a single marker indicated that DM flow calculated from 'day' or 'night' samples was not subject to diurnal variation. In contrast, use of ${ }^{51} \mathrm{Cr}$ as a single marker indicated that fluid flow increased by $1 \cdot 16$ (SE $0 \cdot 27$ ) litres $/ 12 \mathrm{~h}$ during the 'night', assuming a constant rumen pool size.

The flow to the duodenum of NAN, at $24.0-27.7 \mathrm{~g} / \mathrm{d}$, exceeded dietary $\mathrm{N}$ intake by $7 \cdot 2-7.5 \mathrm{~g} / \mathrm{d}$ for sheep given the chopped diet, whereas the difference for the pelleted diet was $5 \cdot 8-6 \cdot 1 \mathrm{~g} / \mathrm{d}$. The corresponding estimates of apparent digestion of $\mathrm{OM}$ in the reticulo-rumen were $384-465 \mathrm{~g} / \mathrm{d}$ for the chopped diet and $343-417 \mathrm{~g} / \mathrm{d}$ for the pelleted diet.

The concentrations of the different markers in duodenal digesta and bacteria are shown in Table 1 . The ${ }^{35} \mathrm{~S}: \mathrm{NAN}$ of bacteria isolated from the fluid phase of rumen and duodenal digesta was similar for both ${ }^{35} \mathrm{~S}$ methods. The ${ }^{35} \mathrm{~S}: \mathrm{NAN}$ in duodenal digesta measured by the B\&F method exceeded $(P<0.05)$ that measured by the M\&F method by $11.3 \mathrm{kBq} / \mathrm{g}$ NAN for the two sheep given the chopped diet but the difference, $4.7 \mathrm{kBq} / \mathrm{g} \mathrm{NAN}$, was not significant $(P<0.05)$ for sheep given the pelleted diet. Measurements of the release of reducible ${ }^{35} \mathrm{~S}$ after the performic acid and $6 \mathrm{M}-\mathrm{HCl}$ hydrolysis steps of the M\&M method showed that the difference between methods observed in the results using duodenal contents was entirely attributable to the release on hydrolysis and precipitation as barium sulphate of 0.28 (SE 0.004) and 0.11 (SE 0.004) of ${ }^{35} \mathrm{~S}$ of the 'organic'-S fraction in sheep given chopped or pelleted canary grass respectively.

In contrast to results obtained by reference to ${ }^{35} \mathrm{~S}$, the incorporation of ${ }^{15} \mathrm{~N}$-labelled NAN into the rumen bacterial fraction was 0.13 higher $(P<0.05)$ than into the bacteria isolated from duodenal fluid (Table 1). 
Table 1. Sulphur content, nitrogen: $S$ and concentration of different bacterial fractions isolated from either rumen fuid or duodenal digesta, and in duodenal digesta from four sheep given either chopped or pelleted reed canary grass (Phalaris arundinacea) with lucerne (Medicago sativa) pellets

\begin{tabular}{|c|c|c|c|}
\hline Form of grass in diet... & Chopped & Pelleted & SD* $^{*}$ \\
\hline \multicolumn{4}{|l|}{ NAN : organic $S$ in: } \\
\hline Rumen bacterial fraction & $20 \cdot 5$ & $20 \cdot 4$ & 0.97 \\
\hline Duodenal bacterial fraction & $16 \cdot 6$ & $18 \cdot 2$ & 0.76 \\
\hline Duodenal digesta & $12 \cdot 4$ & 13.9 & 0.45 \\
\hline \multicolumn{4}{|l|}{ Organic $S$ concentration $\dagger$} \\
\hline \multicolumn{4}{|l|}{ (g/kg DM) in: } \\
\hline Rumen bacterial fraction & $3 \cdot 64$ & 3.55 & $0 \cdot 168$ \\
\hline Duodenal bacterial fraction & $4 \cdot 29$ & 4.08 & $0 \cdot 180$ \\
\hline Duodenal digesta & $2 \cdot 13$ & 1.92 & 0.062 \\
\hline \multicolumn{4}{|l|}{${ }^{35} \mathrm{~S}$ specific activity $\dagger$} \\
\hline \multicolumn{4}{|l|}{$(\mathrm{kBq} / \mathrm{g}$ organic $\mathrm{S})$ in: } \\
\hline Rumen bacterial fraction & 761 & 971 & $32 \cdot 4$ \\
\hline Duodenal bacterial fraction & 612 & 880 & $34 \cdot 1$ \\
\hline Duodenal digesta & 420 & 388 & $15 \cdot 1$ \\
\hline \multicolumn{4}{|l|}{${ }^{35} \mathrm{~S}$ content $\ddagger(\mathrm{kBq} / \mathrm{g}$ NAN) in: } \\
\hline Rumen bacterial fraction & $37 \cdot 1$ & $47 \cdot 6$ & $3 \cdot 39$ \\
\hline Duodenal bacterial fraction & 36.9 & $48 \cdot 4$ & $3 \cdot 73$ \\
\hline Duodenal digesta & 33.9 & $27 \cdot 9$ & 1.56 \\
\hline \multicolumn{4}{|l|}{${ }^{35} \mathrm{~S}$ content $\$(\mathrm{kBq} / \mathrm{g}$ NAN $)$ in: } \\
\hline Rumen bacterial fraction & $37 \cdot 2$ & $45 \cdot 7$ & $2 \cdot 54$ \\
\hline Duodenal bacterial fraction & $37 \cdot 3$ & $43 \cdot 8$ & 1.72 \\
\hline Duodenal digesta & $22 \cdot 6$ & $23 \cdot 2$ & 2.07 \\
\hline \multicolumn{4}{|c|}{${ }^{15} \mathrm{~N}$ enrichment (mmol/mol NAN) in: } \\
\hline Rumen bacterial fraction & $1 \cdot 78$ & $2 \cdot 08$ & 0.023 \\
\hline Duodenal bacterial fraction & 1.52 & 1.92 & 0.023 \\
\hline Duodenal digesta & 0.81 & 0.81 & 0.048 \\
\hline
\end{tabular}

DM, dry matter; NAN, non-ammonia-N.

* Standard deviation based on within-animal variation (df, 8).

$\dagger$ Bird \& Fountain (1970) method (B\&F method).

‡ Calculated from NAN : organic S and ${ }^{35}$ S-specific activity (B\&F method).

$\$$ Mathers \& Miller (1980) method.

Estimates of the proportion of duodenal NAN which was attributable to microbes are presented in Table 2. For sheep given the chopped diet, the B\&F method yielded estimates which were higher than those obtained using the M\&M method $(P<0.05)$ and for those using ${ }^{15} \mathrm{~N}$ as a marker $(P<0.01)$. In contrast, for sheep given pellets all estimates were similar, with the exception that the B\&F method yielded values higher $(P<0.05)$ than that using ${ }^{15} \mathrm{~N}$ as a marker with rumen bacteria as reference.

There were substantial differences $(P<0.05$ after $6 \mathrm{~h}$ of incubation) in values of organic ${ }^{35} \mathrm{~S}$ associated with washed residues from the nylon bags when estimated by either B\&F or M\&M methods (Fig. 1). After $6 \mathrm{~h}$ incubation of feed material in the bag, the magnitude of the difference between methods of measurement for both canary grass and lucerne remained relatively constant, despite an increase in organic ${ }^{35} \mathrm{~S} / \mathrm{g}$ DM measured by both methods (Fig. 1). The proportion of organic ${ }^{35} \mathrm{~S}$ (B\&F method) and ${ }^{15} \mathrm{~N}$ removed on homogenization of the residue was also similar after $6 \mathrm{~h}$ incubation, but substantially more $(P<0.05){ }^{15} \mathrm{~N}$ than ${ }^{35} \mathrm{~S}$ was removed at $3 \mathrm{~h}$ incubation (Fig. 2). The relative amount of microbial $\mathrm{N}$ in bag residues determined using ${ }^{35} \mathrm{~S}$ (M\&M method): microbial $\mathrm{N}$ estimated 
Table 2. Estimates of the proportion of duodenal non-ammonia- $N$ attributed to microbial $N$ by reference to ${ }^{35} S$ or ${ }^{15} \mathrm{~N}$ incorporation into bacteria isolated from rumen fluid or duodenal digesta in four sheep given either chopped or pelleted reed canary grass (Phalaris arundinacea) with lucerne (Medicago sativa) pellets

\begin{tabular}{lccc}
\hline \hline Form of grass in diet... & Chopped & Pelleted & SD $^{*}$ \\
\hline Rumen bacteria as reference: & & & \\
B\&F method & 0.91 & 0.59 & 0.069 \\
M\&M method & 0.61 & 0.51 & 0.0603 \\
'5N method & 0.46 & 0.39 & 0.0254 \\
Duodenal bacteria as reference: & & & \\
B\&F method & 0.92 & 0.58 & 0.073 \\
M\&M method & 0.61 & 0.53 & 0.056 \\
${ }^{15} \mathrm{~N}$ method & 0.53 & 0.42 & 0.029 \\
\hline
\end{tabular}

B\&F, Bird \& Fountain (1970); M\&M, Mathers \& Miller (1980).

* Standard deviation based on within-animal variation.

using ${ }^{15} \mathrm{~N}$ with rumen bacteria as a reference, showed a progressive increase with time of incubation of nylon bags in the rumen (Fig. 3).

Expt 2. The mean ${ }^{35} \mathrm{~S}$ content and specific activity of adherent bacterial preparations isolated from nylon-bag residues increased in a curvilinear fashion with time-period of incubation of nylon bags (Fig. 4). Paired analyses of four samples of isolated adherent bacteria using both B\&F method and $M \& M{ }^{35} \mathrm{~S}$ methods indicated that both methods yielded similar ${ }^{35} \mathrm{~S}: \mathrm{NAN}$ values. Free-living bacteria isolated from the fluid phase of rumen contents as 'loose' and 'firm' pellets respectively (see p. 405) exhibited mean specific radioactivities relative to that of the unfractionated preparation of 0.83 (SE 0.05 ) and 1.13 (SE 0.06).

\section{DISCUSSION}

The use of digesta markers and sampling from a ' $T$ '-piece cannula, suggested by Hogan $\&$ Weston (1967), has been developed by Faichney $(1975,1980)$. The use of a particulate marker (e.g. ${ }^{103} \mathrm{Ru}-\mathrm{P}$, of which $>0.9$ adsorbs on to rumen particulate matter) plus a fluid marker allows for correction for sampling bias involving over- or under-representation of the fluid portion of digesta, which is less of a problem in duodenal than in abomasal sampling. However, the assumptions inherent in this procedure are that steady-state conditions apply to pools and flows of markers. In the present study, it seemed that steady-state conditions did not apply to the flow of ${ }^{51} \mathrm{Cr}$-EDTA and that 'reconstitution' of digesta (Faichney, 1975) in the bulked 'day' and 'night' samples to yield samples allegedly representative of 'true' duodenal digesta would imply that samples obtained from the cannula during the 'day' were deficient in fluid, whereas the opposite would be true for 'night' samples. Application of the 'reconstitution' method to correct for diurnal variation in digesta constituents is valid only insofar as there is constancy of constituent concentrations. This aspect was not investigated in the present experiment and therefore mean values of N flow based on 'day' plus 'night' samples, in which correction for sampling bias was very small or unnecessary, were used.

The disparity between estimates of microbial flow obtained with ${ }^{35} \mathrm{~S}$ (M\&M method) and ${ }^{15} \mathrm{~N}$ incorporation were similar, but in the opposite direction, to those recorded by Siddons et al. (1982) who compared ${ }^{35} \mathrm{~S}$ in methionine and ${ }^{15} \mathrm{~N}$ as microbial markers. The latter 


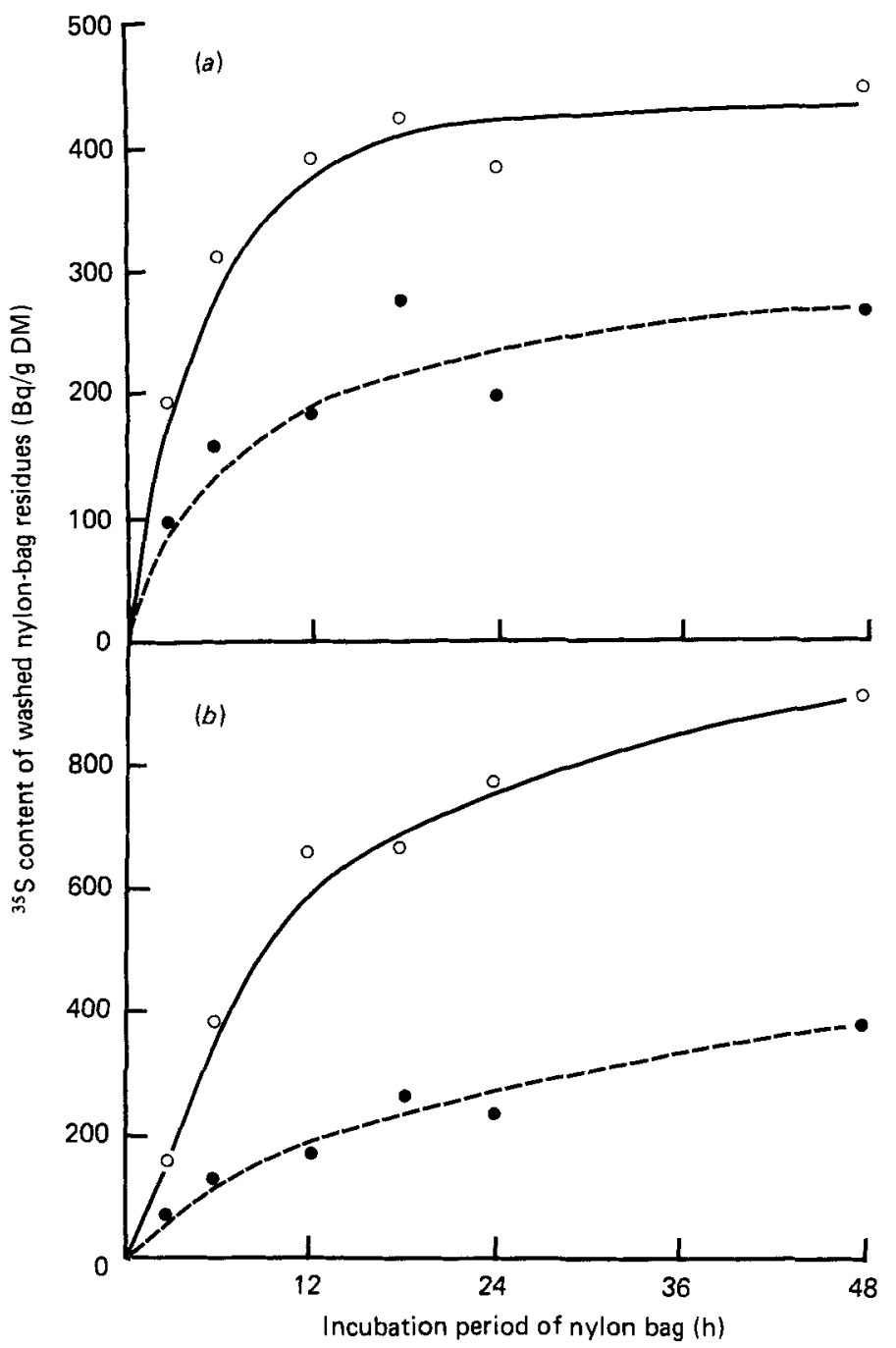

Fig. 1. Changes in ${ }^{95} \mathrm{~S}$ content with period of time in washed nylon-bag residues of $(a)$ reed canary grass (Phalaris arundinacea) or (b) lucerne (Medicago sativa), ${ }^{35} \mathrm{~S}$ was analysed according to Bird \& Fountain (1970) (O) or Mathers \& Miller (1980) (O). DM, dry matter.

authors found that the source of the bacterial reference affected estimates of microbial flow based on $\left[{ }^{35} \mathrm{~S}\right]$ methionine to a lesser extent than those based on ${ }^{15} \mathrm{~N}$, in agreement with the present results, although for their dried-grass diet they found a 0.25 increase $(P<0.05)$ in their estimate of microbial flow when the ${ }^{35}$ S $]$ methionine content of duodenal, rather than rumen microbes was used. However, the present ${ }^{35} \mathrm{~S}$-based results and those of Mathers \& Miller (1980) indicate that differences in estimates were not attributable to the source of bacteria. In the present experiment and in that of Siddons et al. (1982) respectively, there were increased concentrations of organic $S$ and methionine in bacteria isolated from duodenal digesta. Differential lysis, or proteolysis, of microbes passing through the abomasum, and difficulties in obtaining representative samples of the microbes associated with particulate material have been proposed as possible causes for differing marker 


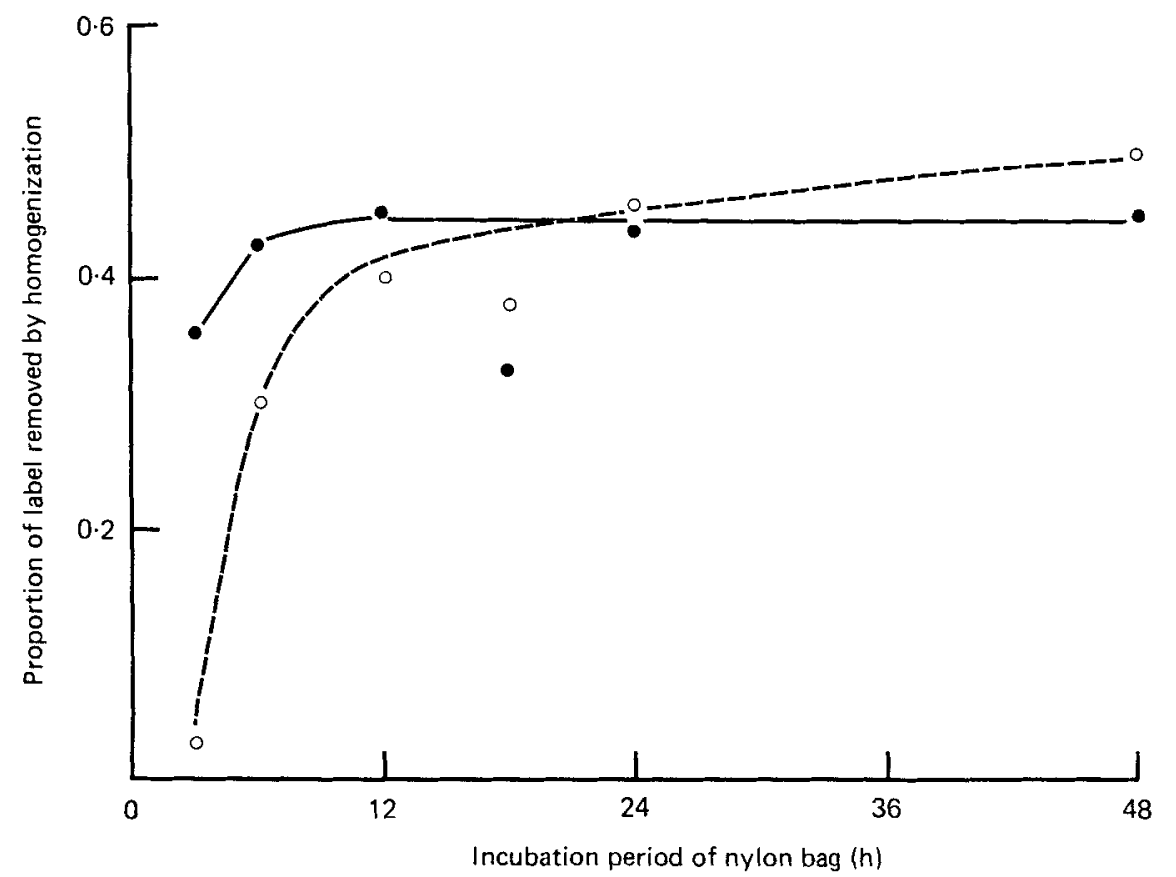

Fig. 2. Proportions of ${ }^{35} \mathrm{~S}\left(\mathrm{O}\right.$, analysed by Bird \& Fountain (1970) method) and ${ }^{15} \mathrm{~N}(\mathrm{O})$ removed by homogenization of washed nylon-bag residues of reed canary grass (Phalaris arundinacea) or lucerne (Medicago sativa).

concentrations in microbial preparations from rumen and duodenal digesta (see Mathers \& Miller, 1980; Siddons et al. 1982). Growth of microbes in the omasum using blood urea-N or epithelial $\mathbf{N}$, both of which would be enriched to a lesser extent than rumen ammonia as a source of $\mathrm{N}$, is also a possible but less likely explanation of differences in ${ }^{15} \mathrm{~N}$ enrichment of microbial fractions isolated from the rumen and duodenum. The marked difference in specific radioactivity between the two fractions of the bacterial pellet centrifuged from rumen fluid in Expt 2 underlines the distinct possibility of an influence of sampling on results. The observation of Hume (1974) that a microbial fraction prepared from omasal fluid had twice the ${ }^{35} \mathrm{~S}$ specific radioactivity of one prepared from duodenal fluid also indicates the variability of ${ }^{35} \mathrm{~S}$ incorporation by different microbial populations.

The estimation in duodenal digesta of material measured as organic ${ }^{35} \mathrm{~S}$ by the $\mathrm{B} \& \mathrm{~F}$ method but which was precipitated as barium sulphate after acid-hydrolysis in the M\&M method was the cause of the marked discrepancy in estimates of net microbial synthesis by the two ${ }^{35} \mathrm{~S}$ methods. The chemical nature of this acid-labile $\mathrm{S}$ is unknown, but it can only be of endogenous or microbial origin. The latter appears more likely, since the specific radioactivity of this $\mathbf{S}$ was similar to that of the isolated and washed bacterial fractions in this experiment and previously similar material appeared to be formed in response to infusion of sulphate into the rumen of sheep given brome grass (Bromus inermis) pellets (Kennedy \& Milligan, 1978a). In the latter experiment there was not a concomitant increase of duodenal microbial flow measured by reference to ${ }^{15} \mathrm{~N}$ incorporation. Furthermore, although Doyle \& Moir (1979) reported flows from the rumen of $0.5-1.0 \mathrm{~g}$ non-protein organic S/d, this was not enhanced by infusion of methionine. One possible source of this acid-labile $\mathbf{S}$ is the extensive extracellular polysaccharide matrix of glycocalyx which forms around stratified layers of adherent bacteria during the rumen colonization of plant tissue 


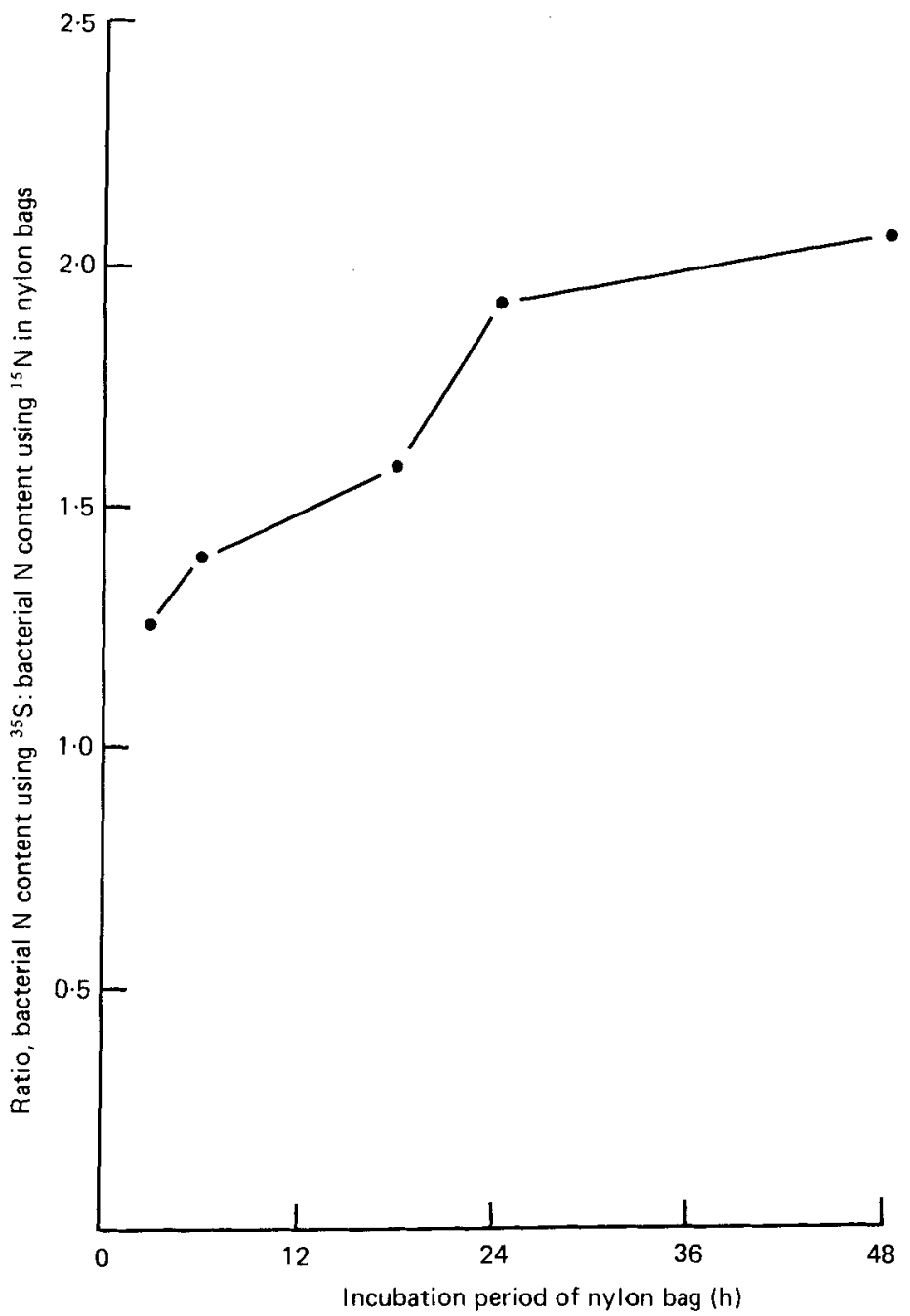

Fig. 3. Ratio, bacterial $\mathrm{N}$ content in washed nylon-bag residues of reed canary grass (Phalaris arundinacea) or lucerne (Medicago sativa) measured by ${ }^{35} \mathrm{~S}$ (Mathers \& Miller, 1980 method): that determined by ${ }^{15} \mathrm{~N}$ incorporation.

(Cheng et al. 1980; Costerton \& Cheng, 1982). Comparatively little is known of the chemical nature of these exopolysaccharides of rumen bacteria, but the production of exopolysaccharide containing ester sulphate groups has been reported in soil bacteria (Fitzgerald, 1976); such a substance may well require more severe conditions for hydrolysis than are provided by the reducing acid mixture used in the B\&F method of $S$ analysis (Roy \& Trudinger, 1970). In support of this proposal, it is interesting to note that significant disparity between values obtained for ${ }^{35} \mathrm{~S}$ radioactivity of microbes by the two analytical methods only occurred in samples which would be expected to contain adherent bacteria (i.e. washed nylon-bag residues, total duodenal contents). Similar values for ${ }^{35}$ S: NAN were obtained by both methods for bacterial preparations which had been isolated from the fluid phase of rumen or duodenal contents, and which would not therefore be expected to contain adherent organisms and their associated glycocalyx material. Available evidence suggests 


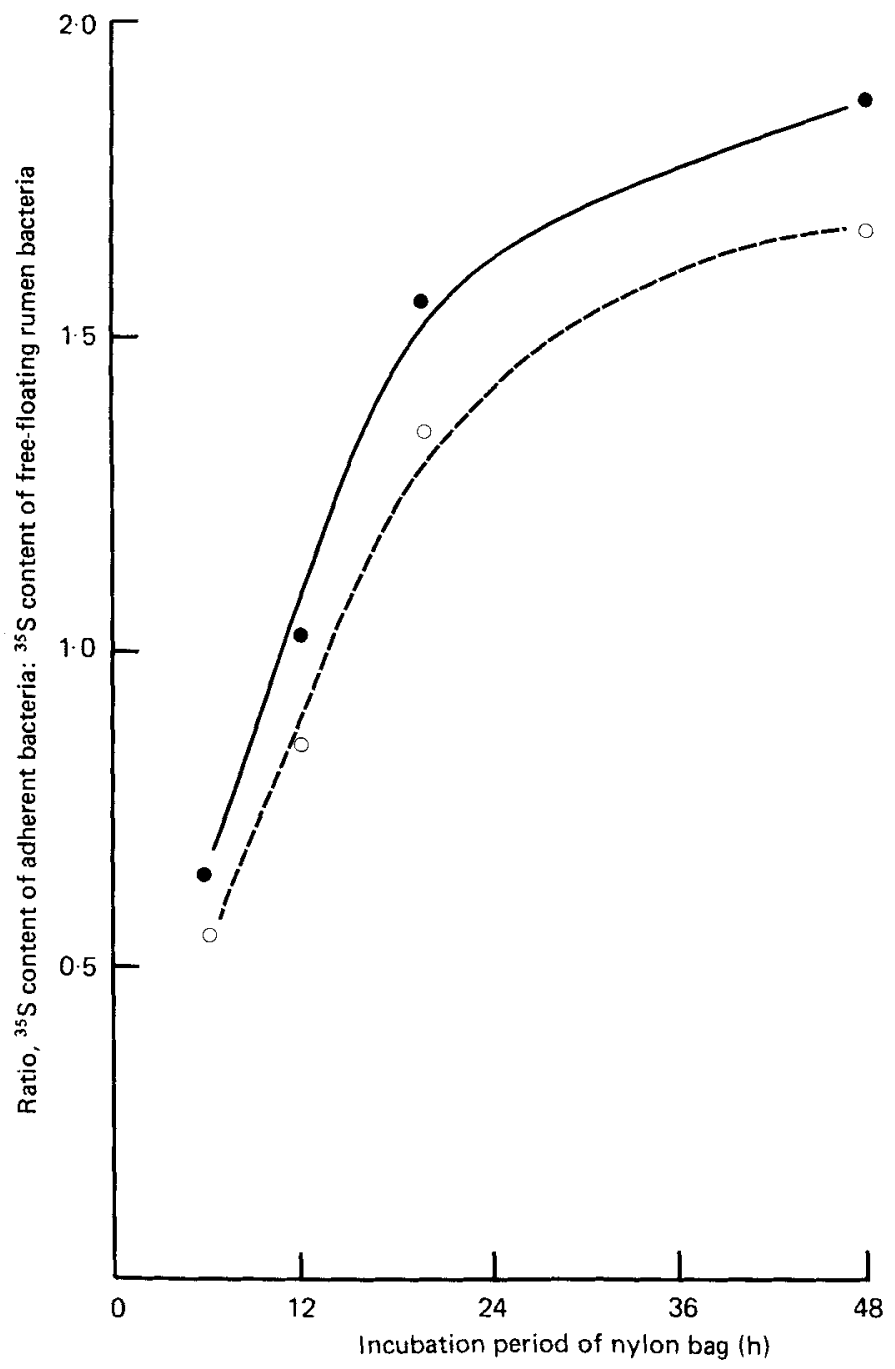

Fig. 4. Expt 2. Changes with duration of incubation period in ${ }^{35} \mathrm{~S}$ content (analysed by method of Bird \& Fountain (1970)) of adherent bacteria removed by homogenization of washed nylon-bag residues of reed canary grass (Phalaris arundinacea) relative to free-floating bacteria in rumen contents. ${ }^{35} \mathrm{~S} / \mathrm{g}$ dry matter (O); ${ }^{35} \mathrm{~S} / \mathrm{g} \mathrm{S}(\mathrm{O})$.

that, for roughage diets, up to 0.75 of rumen bacteria occur in association with fragments of digesta (Forsberg \& Lam, 1977). To the extent that the S and N contents of glycocalyx material produced by adherent bacteria appear to differ from that of washed bacterial cells, it follows that a preparation of rumen bacteria is not an appropriate reference for calculation of duodenal flow of microbial protein unless it contains a representative sample of the adherent population.

Hume (1974) used the ratio, specific ${ }^{35} \mathrm{~S}$-activity (B\&F method) in duodenal digesta : specific ${ }^{35}$ S-activity of microbes isolated from the duodenum to estimate the proportion of duodenal NAN which was contributed by microbes, thereby assuming NAN:organic $S$ of microbes and undegraded dietary material in the abomasum to be similar. Calculations from the present results showed that this method yielded estimates for net microbial synthesis 


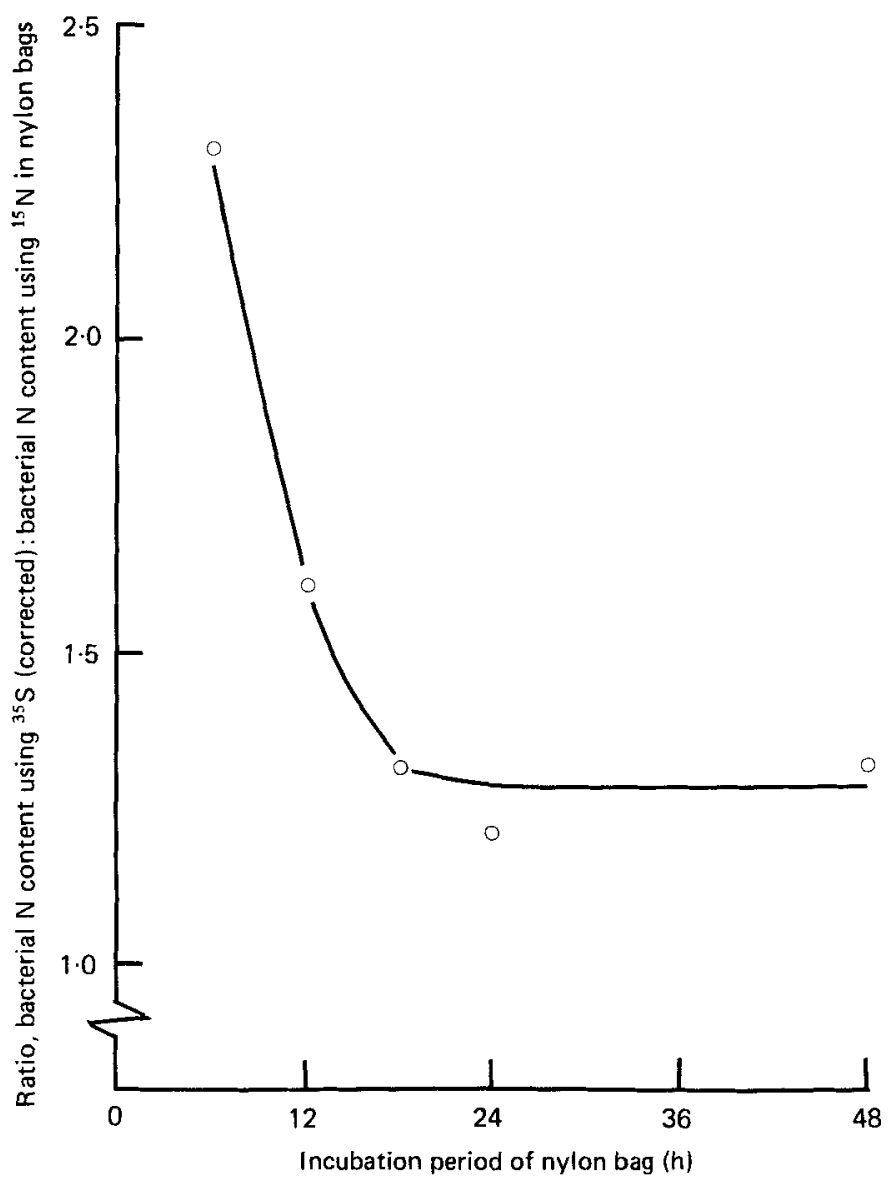

Fig. 5. Expts 1 and 2. Calculated change with incubation period of estimates of bacterial $N$ content of washed nylon-bag residues expressed as the ratio, values calculated from ${ }^{35} \mathrm{~S}$ content : values calculated from ${ }^{15} \mathrm{~N}$ content (Expt 1). ${ }^{35} \mathrm{~S}$ content was calculated using the method of Mathers \& Miller (1980) and corrected for change with time of ${ }^{35} \mathrm{~S}$-labelled adherent bacteria isolated by homogenization of washed nylon-bag residues in Expt 2 (see Fig. 4).

similar to the M\&M method for two sheep, but for the other sheep the values were 1.28 and 0.64 of those using the M\&M method. The results of Hume (1974) for sheep given a semi-purified diet were in good agreement with independent methods for calculating the amount of casein and zein which escaped rumen degradation. It is quite likely that for diets in which much of the carbohydrate is in the form of starch and sucrose, as in the experiments of Hume (1974), adherent bacteria and associated glycocalyx material represent a smaller proportion of the total biomass than for roughage diets. In another study using Hume's (1974) method, but with corrections for non-microbial inorganic ${ }^{35} \mathrm{~S}$ in digesta made after performic acid oxidation and precipitation with barium chloride, Pickering et al. (1982) found close agreement between estimates of microbial flow using ${ }^{35} \mathrm{~S}$ and ${ }^{15} \mathrm{~N}$ incorporation methods for sheep grazing clover and lucerne pastures, but not for sheep grazing a canary-grass pasture. The contributions of differential labelling of adherent and free-living bacteria, 'labile $S$ ' content of digesta and different $N$ :S values of feed residues and bacteria to the results with sheep grazing the canary grass pasture are not clear, but the disparity between ${ }^{35} \mathrm{~S}$ and ${ }^{15} \mathrm{~N}$ incorporation methods to determine microbial flow is another 


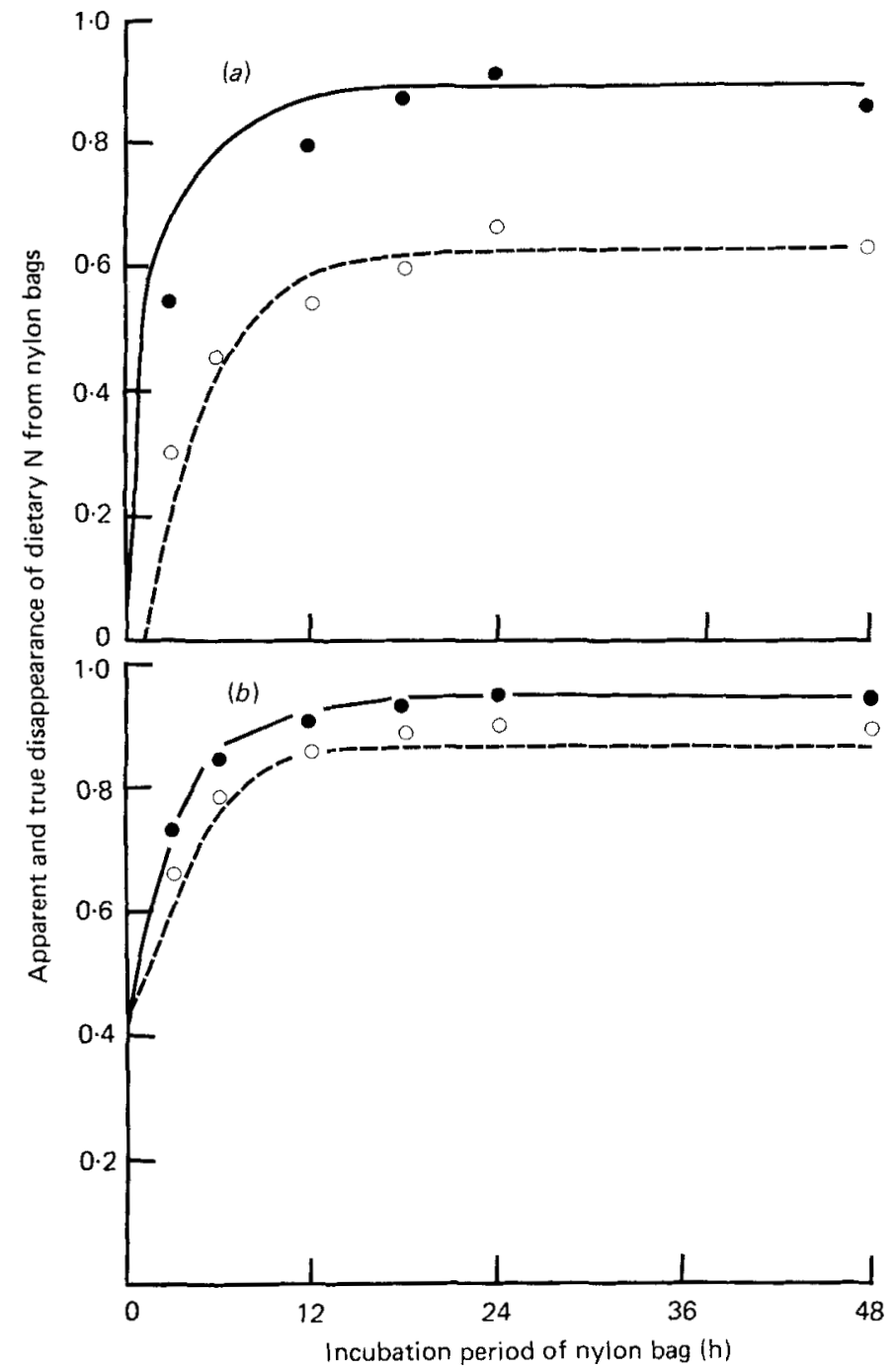

Fig. 6. Apparent $(O)$ and true $(O)$ disappearance of feed nitrogen from washed nylon bags calculated by using the ${ }^{35} \mathrm{~S}$ content of nylon-bag residues to allow for microbial contamination. Method of ${ }^{35} \mathrm{~S}$ assay was that of Mathers \& Miller (1980); values of ${ }^{35} \mathrm{~S}$ : non-ammonia-N in bacteria were corrected for changes in specific radioactivity of adherent bacteria (Fig. 4). Curves fitted by the method of McDonald (1981) were:

(a) Canary grass (Phalaris arundinacea):

$$
\begin{aligned}
& \text { (O) } y=-0 \cdot 223+0 \cdot 854\left(1-\mathrm{e}^{-0 \cdot 237 t}\right) \\
& \text { (O) } y=0.098+0.774\left(1-\mathrm{e}^{-0 \cdot 305 t}\right)
\end{aligned}
$$

(b) Lucerne (Medicago sativa):

(O) $y=0.454+0.444\left(1-\mathrm{e}^{-0 \cdot 221 t}\right)$,

(C) $y=0.498+0.51841 \ldots-0.275 t 3$ 
indication that estimates of microbial growth using ${ }^{35} \mathrm{~S}(\mathrm{~B} \& \mathrm{~F}$ method) may be subject to bias.

Rumen digesta retention time could also influence the difference between estimates obtained using ${ }^{35} \mathrm{~S}$ incorporation measured by either the M\&M or B\&F method. As seen in Fig. 1, during the first $18 \mathrm{~h}$ that hay was in the rumen, there was an increasing difference between results obtained using the two methods for the ${ }^{35} \mathrm{~S}$ content of forage residues in nylon bags. Consistent with this somewhat speculative suggestion, the differences between estimates of microbial content of duodenal digesta derived using the two methods were greater when chopped rather than pelleted reed canary grass was given (Table 2). The pattern of development of material containing $S$ detectable by the B\&F method, but not by the M\&M method ('difference S'), parallels the pattern of decreasing tenacity of binding of microbial S (B\&F method) to forage particles (Fig. 2). The 'difference $S$ ' would then seem to be a microbial product that accumulates after initial colonization of forage particles. Furthermore, the succession of growth of microbes adherent to nylon-bag residues indicated by the change in ${ }^{35} \mathrm{~S}:{ }^{15} \mathrm{~N}$ label with time (Fig. 3) is presumably the explanation for the greater ease of removal of ${ }^{35} \mathrm{~S}$ and ${ }^{15} \mathrm{~N}$ label by homogenization of nylon-bag residues after $12 \mathrm{~h}$ incubation than for shorter incubation periods (Fig. 2).

The increase with time in ${ }^{35} \mathrm{~S}$ content of bacteria adherent to nylon-bag residues isolated by centrifugation in Expt 2 (Fig. 4), and the greater increase with time of incubation in situ for bacterial ${ }^{35} \mathrm{~S}$ than for bacterial ${ }^{15} \mathrm{~N}$ in nylon-bag residues (Fig. 3) are not incompatible with the finding that estimates of microbial $\mathrm{N}$ flow using ${ }^{35} \mathrm{~S}$ (M\&M method) and ${ }^{15} \mathrm{~N}$ were in closer agreement for the chopped than for the pelleted diet. Calculations of the amount of microbial $\mathrm{N}$ in washed nylon-bag residues from ${ }^{35} \mathrm{~S}$ content (M\&M method) corrected for changes in ${ }^{35} \mathrm{~S} / \mathrm{g}$ DM of adherent bacteria (Fig. 4) or on the basis of ${ }^{15} \mathrm{~N}$ content of residues with the enrichment of free-living bacteria isolated from rumen fluid as a reference, show that the estimates tend to converge with prolonged incubation of the bag (Fig. 5).

Lack of agreement between nylon-bag estimates of protein degradability (not corrected for microbial contamination) and in vivo estimates obtained by labelling of plant and microbial fractions using ${ }^{15} \mathrm{~N}$ and ${ }^{35} \mathrm{~S}$, has been noted by Chapman \& Norton (1984). In the present experiment, calculation of the microbial content $(\mathrm{g} \mathrm{N} / \mathrm{g}$ total $\mathrm{N})$ of washed nylon-bag residues showed that it increased from approximately 0.45 at $3 \mathrm{~h}$ to 0.75 at $18-48 \mathrm{~h}$ for canary grass, and from 0.15 to 0.50 for lucerne when the ${ }^{35} \mathrm{~S}$ (M\&M method) content of nylon-bag residues, corrected for changes in specific ${ }^{35} \mathrm{~S}$ activity of adherent bacteria (Fig. 4), was the basis of calculation. As shown in Fig. 6, correction for microbial contamination has a major influence on estimates of feed $\mathrm{N}$ disappearance from nylon bags for reed canary grass, compared with a minor difference only for lucerne, where 0.7 of degradable $\mathrm{N}$ disappeared before $3 \mathrm{~h}$. Therefore, the use of nylon bags to predict digestion of $\mathrm{N}$ of fibrous forages in the rumen will be severely limited in the absence of reliable estimates of microbial content of the residue. Our earlier work (Kennedy et al. 1982) indicating agreement between in vivo and nylon-bag estimates of degradability of chopped brome grass was presumably due to an artefact introduced by the use of the B\&F method of estimation of microbial flow. Escape of feed and endogenous protein from rumen degradation, calculated from the difference between NAN and microbial N flows in the duodenum, was approximately 0.6 of dietary protein intake. For this calculation, the microbial flow was estimated from the incorporation into duodenal bacteria of ${ }^{35} \mathrm{~S}$ (M\&M method) and ${ }^{15} \mathrm{~N}$. Unless chopping of dietary material through the $3 \mathrm{~mm}$ screen grossly enhanced nylon-bag estimates of feed $\mathrm{N}$ digestion, agreement between in vivo and nylon-bag estimates is achieved only if digesta flows at the duodenum were grossly overestimated or if the amount of endogenous NAN appearing at the duodenum was approximately 8-12 $\mathrm{g} \mathrm{N} / \mathrm{d}$. Deducting $2 \mathrm{~g} \mathrm{~N} / \mathrm{d}$ for abomasal secretions (Harrop, 1974), the remaining value of $6-10 \mathrm{~g} \mathrm{~N} / \mathrm{d}$ 
attributable to undegraded endogenous protein reaching the duodenum is similar to other estimates of endogenous protein secreted into the reticulo-rumen (Kennedy \& Milligan, 1980; MacRae \& Reeds, 1980).

The preceding discussion implies that neither ${ }^{35} \mathrm{~S}$ nor ${ }^{15} \mathrm{~N}$ markers of microbial flow to the small intestine are likely to yield consistently reliable values unless microbes adherent to digesta particles can be dislodged without lysis, in order to facilitate isolation of a microbial fraction which is more representative of the biomass flowing into the small intestine than fractions obtained by currently accepted methods. Use of RNA and diaminopimelic acid as microbial markers is subject to similar concern (Merry \& McAllan, 1983). Alternatively, if bacteria are separately prepared from the liquid and solid phases of digesta and flow of digesta is measured, accurate estimates of the marker content of 'average' bacteria may be possible by employing two markers which are incorporated into the two bacterial fractions to different extents by the mathematical methods described by Faichney (1980). We also conclude that in vivo and nylon-bag estimates of rumen degradation of forage diets may be subject to unacceptable errors in their estimation, and methods to allow for accurate estimation of endogenous protein secretions and microbial flow from the rumen are urgently required. Alternatively, methods of directly marking or otherwise identifying plant residues without disturbing normal digestion in the rumen should be sought.

The authors wish to acknowledge assistance from Mrs M. Drury and Mr J. Francis. Dr W. McGill and staff, Department of Soil Science, provided ${ }^{15} \mathrm{~N}$ analyses. Partial financial support from the Natural Sciences and Engineering Research Council of Canada is gratefully acknowledged. G.P.H. was supported by The University of Alberta Endowment Fund for the Future.

\section{REFERENCES}

Agricultural Research Council (1980). The Nutrient Requirements of Ruminant Livestock. Farnham Royal: Commonwealth Agricultural Bureau.

Beever, D. E., Harrison, D. G., Thomson, D. J., Cammell, S. B. \& Osbourn, D. F. (1974). British Journal of Nutrition 32, 99-112.

Bird, R. P. \& Fountain, R. D. (1970). Analyst 95, 98-102.

Chapman, P. G. \& Norton, B. W. (1984). Animal Production in Australia 15, 286-289.

Cheng, K.-J., Fay, J. P., Howarth, R. E. \& Costerton, J. W. (1980). Applied and Environmental Microbiology 40, $613-625$.

Costerton, J. W. \& Cheng, K.-J. (1982). In Experimental Microbial Ecology, pp. 275-290 [R. G. Burns and J. H. Slater, editors]. Oxford: Blackwell Scientific Publications.

Doyle, P. T. \& Moir, R. J. (1979). Australian Journal of Biological Sciences 32, 65-76.

Faichney, G. J. (1975). In Digestion and Metabolism in the Ruminant, pp. 277-291 [1. W. McDonald and A. C. I. Warner, editors]. Armidale: University of New England Publishing Unit.

Faichney, G. J. (1980). Australian Journal of Agricultural Research 31, 1129-37.

Fitzgeraid, J. W. (1976). Bacteriological Reviews 40, 698-721.

Forsberg, C. W. \& Lam, K. (1977). Applied and Environmental Microbiology 33, 528-537.

Gillett, J. A., Bater, D. B. \& Bergen, W. G. (1983). Michigan Agricultural Experimental Station Research Report no. $444,73-77$.

Goering, H. K. \& Van Soest, P. J. (1970). Forage Fiber Analyses. USDA Agriculture Handbook, no. 37. Washington DC: United States Department of Agriculture.

Harrop, C. J. F. (1974). Journal of Agricultural Science, Cambridge 83, 249-257.

Hogan, J. P. \& Weston, R. H. (1967). Australian Journal of Agricultural Research 18, 803-819.

Hume, I. D. (1974). Australian Journal of Agricultural Research 25, 155-165.

Kennedy, P. M., Christopherson, R. J. \& Milligan, L. P. (1982). British Journal of Nutrition 47, $521-535$.

Kennedy, P. M. \& Milligan, L. P. (1978a). British Journal of Nutrition 39, 65-84.

Kennedy, P. M. \& Milligan, L. P. (1978 b). British Journal of Nutrition 39, 105-117.

Kennedy, P. M. \& Milligan, L. P. (1980). Canadian Journal of Animal Science 60, 1029-1032.

Leibholz, J. (1972). Australian Journal of Agricultural Research 23, 1073-1083. 
McDonald, 1. (1981). Journal of Agricultural Science, Cambridge 96, 251-252.

Mackie, R. I., Therion, J. J., Gilchrist, F. M. C. \& Ndhlovu, M. (1983). South African Journal of Animal Science $13,52-54$

MacRae, J. C. \& Reeds, P. J. (1980). In Protein Deposition in Animals, pp. 225-249 [P. J. Buttery and D. B. Lindsay, editors]. London: Butterworths.

Mathets, J. C. \& Aitchison, E. M. (1981). Journal of Agricultural Science, Cambridge 96, 691-693.

Mathers, J. C. \& Miller, E. L. (1980). British Journal of Nutrition 43, 503-514.

Mathison, G. W. \& Milligan, L. P. (1971). British Journal of Nutrition 25, 351-366.

Merry, R. J. \& McAllan, A. B. (1983). British Journal of Nutrition 50, 701-709.

Pickering, F. S., Nolan, J. V. \& Corbett, J. L. (1982). Proceedings of the Nutrition Society of Australia 7, $127-130$.

Roy, A. B. \& Trudinger, P. A. (1970). The Biochemistry of Inorganic Compounds of Sulphur. Cambridge: Cambridge University Press.

Siddons, R. C., Beever, D. E. \& Nolan, J. V. (1982). British Journal of Nutrition 48, 377-389.

Tan, T. N., Weston, R. H. \& Hogan, J. P. (1971). International Journal of Applied Radiation and Isotopes 22, 301-308. 